\title{
Pemanfaatan Pelayanan Kesehatan Ibu di Jawa Barat
}

\author{
Maternal Health Care Utilization in West Java
}

\author{
Yeni Mahwati
}

\section{Sekolah Tinggi Ilmu Kesehatan Dharma Husada Bandung Jawa Barat}

\begin{abstract}
Abstrak
Pemanfaatan pelayanan kesehatan ibu dapat menyelamatkan perempuan dari komplikasi berat dan kematian selama kehamilan, persalinan, dan pasca persalinan. Faktor sosial, manfaat/kebutuhan yang dirasakan, serta aksesibilitas ekonomi dan fisik berkontribusi langsung terhadap pemanfaatan pelayanan kesehatan ibu. Tujuan penelitian ini adalah mengetahui faktor sosial, kebutuhan, serta aksesibilitas ekonomi dan fisik yang memengaruhi pemanfaatan pelayanan kesehatan ibu di Jawa Barat. Data yang digunakan untuk penelitian adalah data sekunder hasil Riset Kesehatan Dasar 2010 pada perempuan usia 15 - 59 tahun yang pernah menikah. Penelitian ini menggunakan analisis bivariat dan multivariat. Kedua hasil analisis menegaskan bahwa faktor sosial, kebutuhan yang dirasakan, serta aksesibilitas ekonomi dan fisik memiliki hubungan yang signifikan dengan pemanfaatan pelayanan antenatal dan persalinan. Model akhir analisis multivariat regresi logistik menunjukkan bahwa tempat tinggal merupakan variabel yang paling memengaruhi pemanfaatan kedua bentuk pelayanan kesehatan ibu. Determinan penting yang lain adalah riwayat komplikasi, pendapatan keluarga, umur, dan pendidikan ibu. Dalam analisis multivariat, status perempuan bekerja dan pekerjaan suami tidak memiliki dampak yang signifikan terhadap kemungkinan perempuan mendapatkan perawatan antenatal dan pemberian perawatan modern meskipun variabel suami adalah positif dan sangat terkait dengan variabel dependen. Kata kunci: Antenatal care, faktor determinan, pelayanan kesehatan ibu, persalinan
\end{abstract}

\footnotetext{
Abstract

Utilization of maternal health care services could save severe complications and death among women during pregnancy, delivery, and after delivery. Numerous factors such as social, perceived needs, and economic and physical accessibility are contributed directly with the use of maternal health care. The purpose of this study is to investigate the social, perceived needs, and economic and physical accecibility factors that affect women's
}

use of maternal health care in West Java. The data used come from the 2010 Basic Health Research of ever married women $15-59$ years old. This study used two levels of analysis, bivariate and multivariate analysis. Both analyses confirmed that social, perceived needs, and economic and physical accessibility factors had a significant relationship with the utilization of antenatal and modern delivery care. The final model logistics regression multivariate analysis indicate that the residence's place remain the most independent variable affecting both of antenatal and delivery care usage. Other important determinants are complications history, family income, mother's age, and education. In the multivariate analysis, the complications history have a significant impact on the probability of women obtaining delivery care although these variable not associated with the dependent variables in the bivariate analysis.

Keywords: Antenatal care, determinant factors, maternal health care, birth delivery

\section{Pendahuluan}

Angka Kematian Ibu (AKI) di Indonesia masih sangat tinggi dibandingkan dengan negara-negara ASEAN yang lain. Pada tahun 1994, AKI di Indonesia dilaporkan 390 per 100.000 kelahiran hidup, menurun menjadi 334 per 100.000 pada tahun 1997 (SDKI) dan 307 per 100.000 kelahiran hidup (SDKI 2002 - 2003). Dalam target MDG's, salah satu upaya yang harus dilakukan untuk meningkatkan kesehatan ibu adalah menurunkan AKI menjadi 102 per 100.000 kelahiran hidup pada tahun 2015.1 Angka ini menunjukkan agenda yang harus dilakukan untuk mencapai target MDG's.

Alamat Korespondensi: Yeni Mahwati, Sekolah Tinggi Ilmu Kesehatan Dharma Husada Bandung, Jl. Terusan Jakarta No. 75, Bandung, Jawa Barat, Hp. 081322801510,e-mail: riza_moms@yahoo.co.id 
Kementerian Kesehatan menyatakan bahwa sembilan provinsi yang dianggap menyumbang 70\% AKI di Indonesia adalah Provinsi Jawa Barat, Jawa Tengah, Jawa Timur, Banten, Sumatera Utara, Sumatera Selatan, DKI Jakarta, Lampung, dan Sulawesi Selatan. ${ }^{2}$ Provinsi Jawa Barat memiliki AKI tertinggi di Indonesia, yaitu sebesar 321 per 100.000 kelahiran hidup dan mengalami penurunan pada tahun 2009 menjadi 123,29 per 100.000 kelahiran hidup. Pada tahun 2010, jumlah kematian ibu sebanyak 804 orang dengan penyebab kematian ibu adalah perdarahan $35 \%$, hipertensi dalam kehamilan $23 \%$, partus lama $1 \%$, infeksi $5 \%$, abortus $1 \%$, dan lain-lain $35 \%$. $^{3}$

Upaya pemerintah untuk menurunkan AKI terkait dengan kehamilan, persalinan, dan nifas telah dimulai sejak akhir tahun 1980-an melalui program Safe Motherhood Initiative. Pada akhir tahun 1990-an, telah diperkenalkan lagi upaya untuk menajamkan strategi dan intervensi dalam menurunkan AKI melalui Making Pregnancy Safer (MPS) yang dicanangkan oleh pemerintah pada tahun 2000 dengan 3 pesan kunci dalam upaya percepatan penurunan angka kematian ibu dan bayi baru lahir, yaitu setiap persalinan ditolong oleh tenaga kesehatan terlatih, setiap komplikasi obstetrik dan neonatal mendapat pertolongan yang adekuat, dan setiap perempuan usia subur mempunyai akses terhadap pencegahan kehamilan yang tidak diinginkan dan penanganan komplikasi pascakeguguran. ${ }^{4}$

Beberapa upaya yang telah dilakukan pemerintah dalam tiga dekade tersebut secara nasional menunjukkan kemajuan yang signifikan dalam peningkatan kesehatan ibu dan anak. Secara nasional, cakupan K1 dan K4, cakupan persalinan oleh tenaga kesehatan dengan kompetensi kebidanan, cakupan pelayanan kesehatan ibu nifas, dan penanganan komplikasi obstetrik mengalami peningkatan sejak 2004 - 2010 walaupun ada yang belum mencapai target rencana strategis Kementerian Kesehatan. ${ }^{5}$ Di Provinsi Jawa Barat, cakupan persalinan oleh tenaga kesehatan pada tahun 2010 telah mencapai $85,21 \%$ dan mengalami peningkatan yang bermakna sejak $2008(74,34 \%)$ dan 2009 (80,47\%). 3 Pencapaian cakupan K1 dan K4 di Jawa Barat adalah sebesar 95,5\% (K1) dan 67,2\% (K4). ${ }^{5}$

Beberapa penelitian sebelumnya telah menunjukkan bahwa pelayanan kesehatan ibu di negara berkembang mempunyai konsekuensi yang signifikan pada daur kehidupan ibu yaitu pada kehamilan dan kelahiran anak, serta kelangsungan hidup dan kesehatan anak selama awal kehamilan. ${ }^{6}$ Penelitian di Vietnam menemukan bahwa pemeriksaan kehamilan mengurangi kematian ibu dengan meningkatkan gizi dan skrining kehamilan risiko tinggi. Di Zaire, perawatan antenatal ditemukan dapat mengurangi kematian ibu sebesar 17 kali lipat. Dampak utama yang dicapai adalah terjadi penurunan pada ane- mia berat, kasus persalinan terhambat, dan pengobatan kondisi medis. Penelitian di Tanzania juga menemukan bahwa $81 \%$ faktor risiko kehamilan dapat diidentifikasi pada periode antenatal. ${ }^{7}$

Demikian pula dengan fasilitas tempat melahirkan yang memadai dan efektif telah dibuktikan secara konsisten dapat mengurangi kematian ibu. Kondisi fasilitas tempat melahirkan yang efektif adalah pertama, kelahiran harus dibantu oleh tenaga kesehatan yang mampu mengidentifikasi tanda-tanda komplikasi dan bertindak tepat ketika terjadi masalah. Kedua, fasilitas rujukan harus tersedia untuk menangani keadaan darurat obstetrik setelah diidentifikasi, mengamati pasien dengan segera saat tiba di fasilitas rujukan, dan melakukan pengambilan keputusan yang tepat untuk menghindari komplikasi lebih lanjut atau bahkan kematian. ${ }^{8}$ Selain itu, diperlukan sistem transportasi yang baik agar perempuan hamil dapat mencapai fasilitas pelayanan secara cepat dan efektif. Namun, di negara berkembang terdapat beberapa faktor yang menjadi hambatan pelayanan kesehatan reproduksi, seperti akses fisik, ekonomi, administratif, kognitif, dan psikososial. ${ }^{9}$

Oleh sebab itu, penelitian ini dilakukan untuk mengungkap berbagai faktor determinan pemanfaatan pelayanan kesehatan ibu, yaitu pelayanan antenatal dan persalinan di Jawa Barat. Faktor determinan dititikberatkan pada kombinasi faktor sosial, manfaat/kebutuhan yang dirasakan, serta aksesibilitas ekonomi dan fisik sesuai dengan modifikasi model Tiga Penundaan (delay) yang diungkapkan oleh Thaddeus dan Maine. ${ }^{10}$ Model tersebut digunakan untuk menganalisis kematian ibu, membedakan antara efek langsung aksesibilitas fisik untuk mencapai fasilitas (delay kedua), dan efek tidak langsung dari persepsi kualitas pelayanan yang dirasakan terhadap keputusan untuk mencari perawatan (delay pertama). Penelitian ini hanya difokuskan pada faktor-faktor determinan pemanfaatan fasilitas pelayanan (delay pertama dan kedua), bukan determinan kematian ibu. Oleh sebab itu, efek langsung dari kualitas pelayanan terhadap delay ketiga tidak diteliti.

Dari sudut pandang kebijakan, penelitian ini diharapkan dapat memberikan informasi baru kepada para pembuat kebijakan dan tenaga pelayanan kesehatan untuk lebih memahami hambatan potensial pemanfaatan pelayanan kesehatan ibu sebagai solusi yang lebih efektif dalam mengurangi kesenjangan akses pelayanan kesehatan yang paling rentan terhadap penduduk di Jawa Barat.

\section{Metode}

Penelitian ini menggunakan data sekunder Riset Kesehatan Dasar (Riskesdas) tahun 2010 dengan desain penelitian cross sectional. Sampel dalam penelitian ini adalah seluruh perempuan berusia 15 - 59 tahun yang 
disurvei dalam Riskesdas 2010 berjumlah 2.320 orang. Pada pemilihan sampel, proses cleaning dilakukan dengan mengeluarkan 111 data missing dan 80 jawaban "tidak tahu" sehingga analisis hanya dilakukan pada 2.129 sampel perempuan.

Data dalam variabel penelitian diperoleh berdasarkan instrumen yang digunakan dalam Riskesdas 2010. Analisis data yang digunakan dalam penelitian ini adalah analisis univariat untuk memberikan deskripsi dari seluruh variabel penelitian yang dianalisis, analisis bivariat untuk menguji hubungan antara variabel-variabel independen dengan dua variabel dependen menggunakan uji chi-square, dan analisis multivariat untuk menjelaskan sifat variabel prediktor dan kontribusi relatif mereka dalam menjelaskan variabel terikat. Oleh sebab kedua variabel dependen dalam analisis ini adalah dikotom, analisis regresi logistik digunakan untuk memprediksi hubungan antara variabel dependen dan variabel independen.
Hasil

Distribusi faktor determinan pemanfaatan pelayanan kesehatan ibu tercantum pada Tabel 1 . Sebagian besar umur ibu 20 - 34 tahun $(66,5 \%)$, pendidikan dasar $(61,7 \%)$, dan pendidikan suami dengan pendidikan dasar (55\%). Dari faktor kebutuhan seki$\operatorname{tar} 71,6 \%$ subjek menginginkan kehamilan dan mempunyai $2-3$ anak, sebagian besar perempuan yang diteliti tidak mengalami komplikasi. Ditinjau akses ekonomi sebagian besar subjek tidak bekerja dan suami bekerja sebagai petani/buruh/nelayan dengan pendapatan keluarga berada pada kuintil 3. Ditinjau dari akses tempat tinggal lebih dari separuh subjek bermukin di perkotaan $(63,2 \%)$ yang selanjutnya variabel ini digunakan sebagai proksi penentu ketersediaan pelayanan.

Pada analisis bivariat ditinjau dari faktor sosial, faktor kebutuhan, akses ekonomi dan fisik, ditemukan delapan variabel yang memenuhi kriteria kandidat

Tabel 1. Distribusi Faktor Determinan Pemanfaatan Pelayanan Kesehatan Ibu di Jawa Barat

\begin{tabular}{|c|c|c|c|}
\hline Variabel & Kategori & $\mathbf{n}$ & Persentase $(\%)$ \\
\hline \multicolumn{4}{|l|}{ Faktor Sosial } \\
\hline \multirow[t]{3}{*}{ Umur ibu } & 15-19 tahun & 82 & 3,9 \\
\hline & 20-34 tahun & 1.416 & 66,5 \\
\hline & $35-59$ tahun & 631 & 29,6 \\
\hline \multirow[t]{4}{*}{ Pendidikan ibu } & Tidak sekolah/tidak tamat SD/MI & 188 & 8,8 \\
\hline & Pendidikan dasar & 1.314 & 61,7 \\
\hline & Pendidikan menengah & 480 & 22,5 \\
\hline & Pendidikan tinggi & 147 & 6,9 \\
\hline \multirow[t]{4}{*}{ Pendidikan suami } & Tidak sekolah/tidak tamat SD/MI & 192 & 9,0 \\
\hline & Pendidikan dasar & 1.170 & 55,0 \\
\hline & Pendidikan menengah & 571 & 26,8 \\
\hline & Pendidikan tinggi & 196 & 9,2 \\
\hline \multicolumn{4}{|l|}{ Faktor kebutuhan } \\
\hline \multirow[t]{3}{*}{ Keinginan hamil } & Tidak menginginkan & 221 & 10,4 \\
\hline & Menginginkan kemudian & 384 & 18,0 \\
\hline & Menginginkan & 1.524 & 71,6 \\
\hline \multirow[t]{4}{*}{ Urutan kelahiran } & 1 & 646 & 30,3 \\
\hline & $2-3$ & 1.145 & 53,8 \\
\hline & $4-5$ & 267 & 12,5 \\
\hline & 6 atau lebih & 71 & 3,3 \\
\hline \multirow[t]{2}{*}{ Riwayat komplikasi } & Tidak ada & 1.987 & 91,2 \\
\hline & Ada & 142 & 6,2 \\
\hline \multicolumn{4}{|l|}{ Akses ekonomi } \\
\hline \multirow[t]{4}{*}{ Pekerjaan ibu } & Tidak bekerja/sekolah & 1.453 & 68,2 \\
\hline & Petani/nelayan/buruh/lainnya & 401 & 18,8 \\
\hline & Wiraswasta/jasa/pedagang & 185 & 8,7 \\
\hline & TNI/Polri/PNS/pegawai & 90 & 4,2 \\
\hline \multirow[t]{4}{*}{ Pekerjaan suami } & Tidak bekerja & 19 & 0,9 \\
\hline & Petani/nelayan/buruh/lainnya & 918 & 43,1 \\
\hline & Wiraswasta/jasa/pedagang & 898 & 42,2 \\
\hline & TNI/Polri/PNS/pegawai & 294 & 13,8 \\
\hline \multirow[t]{5}{*}{ Pendapatan keluarga } & Kuintil 1 & 448 & 21,0 \\
\hline & Kuintil 2 & 481 & 22,6 \\
\hline & Kuintil 3 & 465 & 21,8 \\
\hline & Kuintil 4 & 404 & 19,0 \\
\hline & Kuintil 5 & 331 & 15,5 \\
\hline \multicolumn{4}{|l|}{ Akses fisik } \\
\hline \multirow[t]{2}{*}{ Tempat tinggal } & Perdesaan & 783 & 36,8 \\
\hline & Perkotaan & 1.346 & 63,2 \\
\hline
\end{tabular}


Tabel 2. Hasil Analisis Bivariat Faktor Determinan Pelayanan Kesehatan Berdasarkan Faktor Sosial dan Kebutuhan

\begin{tabular}{|c|c|c|c|c|c|c|c|}
\hline \multirow{2}{*}{ Variabel } & \multirow{2}{*}{ Kategori } & \multicolumn{3}{|c|}{ Pelayanan ANC } & \multicolumn{3}{|c|}{ Persalinan Yankes } \\
\hline & & Adekuat & Tidak & Nilai $p$ & Tidak & Ya & Nilai p \\
\hline \multicolumn{8}{|l|}{ Faktor Sosial } \\
\hline \multirow[t]{3}{*}{ Umur ibu } & 15-19 tahun & 9,8 & 90,2 & 0,732 & 63,4 & 36,6 & 0,000 \\
\hline & 20-34 tahun & 10,3 & 89,7 & & 48,6 & 51,4 & \\
\hline & $35-59$ tahun & 11,4 & 88,6 & & 41,0 & 59,0 & \\
\hline \multirow[t]{4}{*}{ Pendidikan ibu } & $<$ Pendidikan dasar & 21,8 & 78,2 & 0,000 & 70,7 & 29,3 & 0,000 \\
\hline & Pendidikan dasar & 12,7 & 87,3 & & 57,9 & 42,1 & \\
\hline & Pendidikan menengah & 2,9 & 97,1 & & 19,6 & 80,4 & \\
\hline & Pendidikan tinggi & 2,7 & 97,3 & & 7,5 & 92,5 & \\
\hline \multirow[t]{4}{*}{ Pendidikan suami } & $<$ Pendidikan dasar & 19,3 & 80,7 & 0,000 & 67,2 & 32,8 & 0,000 \\
\hline & Pendidikan dasar & 14,1 & 85,9 & & 60,6 & 39,4 & \\
\hline & Pendidikan menengah & 3,2 & 96,8 & & 24,5 & 75,5 & \\
\hline & Pendidikan tinggi & 3,1 & 96,9 & & 10,7 & 89,3 & \\
\hline \multicolumn{8}{|l|}{ Faktor kebutuhan } \\
\hline \multirow[t]{3}{*}{ Keinginan hamil } & Tidak mengingikan & 12,2 & 87,8 & 0,382 & 42,5 & 57,5 & 0,330 \\
\hline & Menginginkan kemudian & 8,9 & 91,1 & & 48,7 & 51,3 & \\
\hline & Menginginkan & 10,8 & 89,2 & & 47,1 & 52,9 & \\
\hline \multirow[t]{4}{*}{ Urutan kelahiran } & 1 & 9,1 & 90,9 & 0,000 & 44,0 & 56,0 & 0,003 \\
\hline & $2-3$ & 9,5 & 90,5 & & 46,2 & 53,8 & \\
\hline & $4-5$ & 15,4 & 84,6 & & 52,8 & 47,2 & \\
\hline & 6 atau lebih & 23,9 & 76,1 & & 63,4 & 36,6 & \\
\hline \multirow[t]{2}{*}{ Riwayat komplikasi } & Tidak ada & 11,0 & 89,0 & 0,064 & 48,0 & 48,0 & 0,000 \\
\hline & Ada & 5,6 & 94,4 & & 31,7 & 31,7 & \\
\hline
\end{tabular}

Tabel 3. Hasil Analisis Bivariat Faktor Determinan Pelayanan Kesehatan Berdasarkan Akses Ekonomi dan Fisik

\begin{tabular}{|c|c|c|c|c|c|c|c|}
\hline \multirow{2}{*}{ Variabel } & \multirow{2}{*}{ Kategori } & \multicolumn{3}{|c|}{ Pelayanan ANC } & \multicolumn{3}{|c|}{ Persalinan tenaga kesehatan } \\
\hline & & Adekuat & Tidak & Nilai $p$ & Ya & Tidak & Nilai $p$ \\
\hline \multicolumn{8}{|l|}{ Akses ekonomi } \\
\hline \multirow[t]{4}{*}{ Pekerjaan ibu } & Tidak bekerja/sekolah & 10,9 & 89,1 & 0,030 & 48,3 & 51,7 & 0,000 \\
\hline & Petani/nelayan/buruh/lain & 6,5 & 87,3 & & 54,6 & 45,4 & \\
\hline & Wiraswasta/jasa/pedagang & 4,4 & 93,5 & & 36,8 & 63,2 & \\
\hline & TNI/Polri/PNS/pegawai & 12,7 & 95,6 & & 11,1 & 88,9 & \\
\hline \multirow[t]{4}{*}{ Pekerjaan suami } & Tidak bekerja/sekolah & 0,0 & 100,0 & 0,000 & 52,6 & 47,4 & 0,000 \\
\hline & Petani/nelayan/buruh/lain & 14,7 & 85,3 & & 62,1 & 37,9 & \\
\hline & Wiraswasta/jasa/pedagang & 8,9 & 91,1 & & 40,8 & 54,2 & \\
\hline & TNI/Polri/PNS/pegawai & 3,7 & 96,3 & & 18,0 & 82,0 & \\
\hline \multirow[t]{5}{*}{ Pendapatan keluarga } & Kuintil 1 & 20,5 & 79,5 & 0,000 & 69,9 & 30,1 & 0,000 \\
\hline & Kuintil 2 & 13,1 & 86,9 & & 60,5 & 39,5 & \\
\hline & Kuintil 3 & 8,6 & 91,4 & & 47,3 & 52,7 & \\
\hline & Kuintil 4 & 5,2 & 94,8 & & 30,4 & 69,6 & \\
\hline & Kuintil 5 & 3,0 & 97,0 & & 15,7 & 84,3 & \\
\hline \multicolumn{8}{|l|}{ Akses fisik } \\
\hline \multirow[t]{2}{*}{ Tempat tinggal } & Pedesaan & 16,7 & 83,3 & 0,000 & 72,4 & 72,4 & 0,000 \\
\hline & Perkotaan & 7,1 & 92,9 & & 32,1 & 32,1 & \\
\hline
\end{tabular}

model multivariat determinan pemanfaatan pelayanan antenatal care dengan nilai $\mathrm{p}<0,25$ meliputi pendidikan ibu dan suami, urutan kelahiran, riwayat komplikasi, pekerjaan ibu dan suami, pendapatan keluarga, serta tempat tinggal, sedangkan umur ibu tidak memenuhi kriteria multivariat untuk pemanfaatan pelayanan kesehatan $(\mathrm{p}=0,732)$, namun memenuhi untuk persalinan di pelayanan kesehatan $(\mathrm{p}=0,000)$ (Tabel 2 dan 3).

Dalam model ini, terlihat terdapat lima determinan penting yang berpengaruh terhadap pemanfaatan pelayanan persalinan, yaitu umur ibu, pendidikan ibu, riwayat komplikasi, pendapatan keluarga, dan tempat tinggal. Faktor determinan terkuat adalah tempat tinggal, selanjutnya determinan lain adalah riwayat komplikasi, pendapatan keluarga, umur ibu, dan pendidikan ibu (Tabel 4).

Perempuan yang tinggal di daerah perkotaan berpeluang 4,01 kali $(\mathrm{CI}=3,28-4,91)$ untuk memilih bersalin di fasilitas kesehatan dibandingkan dengan 
Tabel 4. Hasil Analisis Multivariat Regresi Logistik Model Terakhir Pelayanan ANC

\begin{tabular}{|c|c|c|c|c|c|}
\hline Variabel & Kategori & Koefisien (B) & Nilai $p$ & OR & $\mathbf{9 5} \%$ IK \\
\hline \multirow[t]{3}{*}{ Umur ibu } & 15-19 tahun (ref) & & 0,000 & & \\
\hline & $20-34$ tahun & $-0,792$ & 0,004 & 0,453 & $0,27-0,77$ \\
\hline & $35-59$ tahun & $-0,471$ & 0,000 & 0,624 & $0,50-0,78$ \\
\hline \multirow[t]{4}{*}{ Pendidikan ibu } & Tidak sekolah (ref) & & 0,000 & & \\
\hline & Pendidikan dasar & $-2,174$ & 0,000 & 0,114 & $0,05-0,24$ \\
\hline & Pendidikan menengah & $-1,810$ & 0,000 & 0,164 & $0,08-0,32$ \\
\hline & Pendidikan tinggi & $-0,727$ & 0,039 & 0,484 & $0,24-0,96$ \\
\hline \multirow[t]{2}{*}{ Riwayat komplikasi } & Tidak ada (ref) & & 0,000 & & \\
\hline & Ada & 0,569 & 0,009 & 1,766 & $1,15-2,70$ \\
\hline \multirow[t]{5}{*}{ Pendapatan Keluarga } & Kuintil 1 (ref) & & 0,000 & & \\
\hline & Kuintil 2 & $-1,551$ & 0,000 & 0,212 & $0,14-0,32$ \\
\hline & Kuintil 3 & $-1,299$ & 0,000 & 0,273 & $0,18-0,41$ \\
\hline & Kuintil 4 & $-0,800$ & 0,000 & 0,449 & $0,30-0,67$ \\
\hline & Kuintil 5 & $-0,416$ & 0,043 & 0,659 & $0,44-0,99$ \\
\hline \multirow[t]{2}{*}{ Tempat tinggal } & Pedesaan (ref) & & & & \\
\hline & Perkotaan & 1,389 & 0,000 & 4,011 & $3,28-4,90$ \\
\hline Jumlah kasus & & 2.260 & & & \\
\hline-2 Log likelihood & & 2275,045 & & & \\
\hline $\mathrm{G}$ & & 668,310 & & & \\
\hline Nilai $\mathrm{p}$ & & 0,000 & & & \\
\hline
\end{tabular}

Tabel 5. Hasil Analisis Multivariat Regresi Logistik Model Terakhir Persalinan Pelayanan Kesehatan

\begin{tabular}{lcccc}
\hline Variabel & Koefisien (B) & Nilai p & OR & 95\% IK \\
\hline $\begin{array}{l}\text { Tempat tinggal } \\
\text { Pedesaan (ref) }\end{array}$ & & & & \\
Perkotaan & 0,973 & 0,000 & 12,646 & $1,999-3,503$ \\
Jumlah kasus & 2.129 & & & \\
-2 Log likelihood & 1394,010 & & & \\
G & 46,880 & & & \\
Nilai p & 0,000 & & \\
\hline
\end{tabular}

perempuan yang tinggal di perdesaan. Perempuan yang mempunyai riwayat komplikasi berpeluang sebesar 1,77 kali $(\mathrm{CI}=1,15-2,70)$ untuk memilih bersalin di fasilitas kesehatan dibandingkan dengan perempuan yang tidak mempunyai riwayat komplikasi. Perempuan berumur $20-34$ tahun berpeluang 0,45 kali $(\mathrm{CI}=0,26-0,77)$ dan perempuan berumur $>35$ tahun berpeluang 0,62 kali $(\mathrm{CI}=0,50-0,78)$ untuk memanfaatkan fasilitas persalinan dibandingkan dengan perempuan berumur 15 - 19 tahun sebagai kelompok referensi. Perempuan yang mempunyai pendapatan keluarga pada kuintil yang lebih tinggi mempunyai peluang lebih besar untuk memilih persalinan di fasilitas kesehatan. Perempuan dengan pendidikan dasar berpeluang 0,11 kali $(\mathrm{CI}=0,05-0,24)$, perempuan dengan pendidikan menengah berpeluang 0,16 kali $(\mathrm{CI}=0,08$ 0,32 ), dan perempuan dengan pendidikan tinggi berpeluang terbesar, yaitu 0,48 kali $(\mathrm{CI}=0,24-0,96)$ untuk bersalin di fasilitas pelayanan kesehatan dibandingkan dengan perempuan pada kelompok referensi (Tabel 4).
Dalam model ini, determinan yang paling berpengaruh terhadap pemanfaatan pelayanan antenatal adalah tempat tinggal. Hal ini berarti bahwa perempuan yang tinggal di perkotaan mempunyai peluang 13 kali $(\mathrm{CI}=1,999-3,503)$ untuk mendapatkan pelayanan antenatal care yang adekuat dibandingkan dengan perempuan yang tinggal di daerah perdesaan (Tabel 5).

\section{Pembahasan}

Hasil penelitian menggambarkan determinan sosial serta aksesibilitas ekonomi dan fisik yang berpengaruh terhadap pemanfaatan pelayanan kesehatan ibu, meliputi pelayanan ANC dan persalinan. Usia berperan penting dalam pemanfaatan pelayanan kesehatan ibu. ${ }^{10}$ Namun, hasil penelitian ini tidak sepenuhnya mendukung temuan tersebut. Hubungan yang signifikan hanya ditemukan pada pelayanan persalinan, tidak pada pelayanan ANC. Pola pemanfaatan pelayanan persalinan mengikuti bentuk "J", dengan puncak pada perempuan berusia $35-59$ tahun. Usia berkaitan dengan pengetahuan dan pengalaman. Remaja dan usia reproduksi sehat belum mempunyai pengetahuan yang cukup dan pengalaman tentang pentingnya persalinan dilakukan di fasilitas kesehatan. Perempuan yang lebih tua mungkin merasa mempunyai pengetahuan tentang risiko kehamilan yang lebih besar, sehingga mereka lebih memilih fasilitas kesehatan sebagai tempat persalinan.

Pendidikan ibu berhubungan signifikan dengan pemanfaatan kedua pelayanan kesehatan ibu. Hasil temuan tersebut konsisten dengan penelitian se- 
belumnya. Di Peru, pendidikan formal perempuan memengaruhi penggunaan pelayanan kesehatan ibu. ${ }^{11}$ Di Thailand, pendidikan ibu berpengaruh signifikan terhadap pemanfaatan pelayanan kesehatan. Peluang memanfaatkan pelayanan kehamilan dan persalinan di fasilitas pelayanan kesehatan jauh lebih besar pada perempuan sekolah dasar dibanding perempuan yang tidak sekolah. ${ }^{12}$

Pendidikan suami berhubungan signifikan dengan pemanfaatan kedua pelayanan kesehatan ibu. Suami berpendidikan lebih terbuka terhadap pengobatan modern, menyadari manfaat pertolongan persalinan oleh tenaga kesehatan yang terampil, lebih mampu berkomunikasi dengan petugas kesehatan, dan mempunyai kebutuhan terhadap perawatan yang tepat. ${ }^{12}$ Hampir semua studi yang menunjukkan bahwa pendidikan suami yang lebih tinggi berhubungan dengan pemanfaatan tenaga kesehatan sebagai penolong persalinan meskipun seringkali berefek relatif lebih rendah daripada pendidikan ibu. ${ }^{10}$

Perempuan dengan kehamilan pertama lebih mungkin mencari pelayanan kesehatan ibu pada kelahiran pertama dibandingkan dengan urutan kelahiran yang lebih tinggi. Perempuan yang memiliki banyak anak cenderung mendapatkan pelayanan antenatal yang tidak adekuat dan memilih untuk bersalin di rumah. Bukti tersebut menunjukkan bahwa perempuan dengan banyak anak cenderung lebih mengabaikan kesehatan mereka sendiri selama kehamilan, meskipun pelayanan tersebut sangat penting untuk mencegah risiko komplikasi kehamilan dan risiko kematian yang mungkin terjadi saat persalinan. Penelitian di India menunjukkan bahwa pemanfaatan pelayanan antenatal yang adekuat (15\%), persalinan yang aman $(53 \%)$, dan perawatan pascakelahiran (37\%) lebih tinggi di antara perempuan yang melahirkan anak pertama dibandingkan pada perempuan yang mempunyai pengalaman kelahiran sebelumnya. ${ }^{13}$ Perempuan dengan riwayat komplikasi cenderung bersalin di fasilitas kesehatan. Komplikasi yang dialami pada persalinan sebelumnya atau bayi baru lahir meninggal dapat membuat perempuan sadar bahaya persalinan dan manfaat pertolongan persalinan oleh tenaga terampil, sehingga mendorong pemanfaatan tenaga terampil pada persalinan selanjutnya. ${ }^{8}$

Konsisten dengan penelitian sebelumnya, faktor determinan ekonomi seperti pekerjaan ibu, pekerjaan suami, dan pendapatan keluarga meningkatkan peluang mendapatkan pelayanan antenatal yang memadai dan persalinan di fasilitas kesehatan. Partisipasi ekonomi ibu dapat menyebabkan peningkatan pemanfaatan pelayanan kesehatan karena bekerja akan membuat perempuan bersosialisasi di luar rumah dan kesadaran akan kenaikan gaji pada akhirnya mengubah perilaku. Penelitian di Kenya menemukan bahwa kunjungan ANC cenderung dilakukan bagi perempuan yang bekerja. ${ }^{14}$ Mereka cenderung mempunyai pengetahuan lebih baik tentang kehamilan dan persalinan karena kebebasan bergerak di luar rumah. Mereka juga cenderung mencari informasi tentang pelayanan perawatan kehamilan yang tersedia selama bekerja. Status pekerjaan suami yang mewakili pendapatan dan kemapanan keluarga berefek positif pada pemanfaatan pelayanan kesehatan modern. ${ }^{11}$

Tempat tinggal juga berhubungan signifikan dengan pemanfaatan pelayanan. Perempuan yang tinggal di daerah perkotaan lebih mungkin memanfaatkan pelayanan kesehatan ibu karena kondisi infrastruktur yang lebih menguntungkan dibandingkan dengan perempuan yang tinggal di perdesaan. ${ }^{15}$ Hasil penelitian ini menunjukkan proporsi persalinan di fasilitas kesehatan lebih tinggi pada perempuan yang tinggal di perkotaan dibandingkan dengan perdesaan.

Selanjutnya, hasil analisis multivariat menunjukkan bahwa tempat tinggal merupakan prediktor kuat dalam pemanfaatan kedua jenis pelayanan kesehatan ibu (Tabel 5). Sesuai dengan Peraturan Badan Pusat Statistik Nomor 37 tahun 2010, daerah perdesaan adalah suatu wilayah administratif setingkat desa/kelurahan yang belum memenuhi persyaratan tertentu dalam hal kepadatan penduduk, persentase rumah tangga pertanian dan sejumlah fasilitas perkotaan, sarana pendidikan formal, sarana kesehatan umum, dan sebagainya. ${ }^{16}$ Dengan demikian jelas bahwa daerah yang masuk dalam kriteria perdesaan masih belum memenuhi persyaratan yang salah satunya adalah akses terhadap sarana kesehatan. Hambatan fisik berupa jarak yang jauh, kondisi jalan, dan ketersediaan transportasi menyebabkan ibu yang tinggal di perdesaan kurang mendapatkan akses pelayanan kesehatan. Waktu tempuh untuk mendapat pelayanan juga sangat berarti dalam kondisi kegawatdaruratan.

Riwayat komplikasi, pendapatan keluarga, umur, dan pendidikan ibu juga menjadi faktor determinan penting dalam pemanfaatan tempat persalinan. Hal ini disebabkan kesadaran perempuan akan potensi risiko kehamilan dan kelahiran, sehingga perempuan dengan riwayat komplikasi lebih memilih bersalin di tempat yang mempunyai fasilitas lebih memadai. Biaya dalam pencarian pelayanan mencakup biaya transportasi, obat dan perlengkapan, institusi pelayanan, biaya perjalanan, dan biaya kehilangan waktu produktif. Peningkatan biaya ini dimungkinkan karena seorang perempuan tidak menanggung sendiri seluruh biaya, tetapi bersama keluarga sehingga biaya transportasi dan pengina- 
pan dapat terpenuhi. Rumah tangga dengan anggaran yang ketat akan mengalami kesulitan besar untuk membayar biaya ini. Oleh sebab itu, lebih kecil kemungkinan untuk menggunakan fasilitas kesehatan untuk persalinan. ${ }^{8}$ Usia sangat berhubungan dengan paritas dan di beberapa tempat dengan tingkat pendidikan. Hal ini juga terkait dengan status perkawinan, keinginan kehamilan, status sosial ekonomi, dan kekuasaan pengambilan keputusan. ${ }^{14}$ Perempuan yang lebih tua lebih percaya diri dan berpengaruh dalam pengambilan keputusan rumah tangga dibandingkan perempuan yang lebih muda, khususnya para remaja. Di sisi lain, perempuan yang lebih tua dapat lebih memegang tradisi sehingga kecil kemungkinan menggunakan fasilitas modern daripada perempuan muda. ${ }^{17}$ Pendidikan memungkinkan meningkatkan otonomi perempuan, sehingga perempuan mempunyai keyakinan yang lebih besar dan kemampuan mengambil keputusan mengenai kesehatan mereka sendiri. ${ }^{12}$ Pendidikan juga memungkinkan perempuan untuk mempunyai pengetahuan yang lebih baik dan informasi di bidang kesehatan modern dan mempunyai kapasitas yang lebih besar untuk mengenali penyakit tertentu.

\section{Kesimpulan}

Penelitian ini menemukan bahwa faktor determinan sosial, kebutuhan, serta aksesibilitas ekonomi dan fisik dapat membentuk perilaku pemanfaatan pelayanan kesehatan ibu. Hasil ini pada umumnya juga konsisten dengan penelitian sebelumnya. Kedua hasil analisis baik bivariat maupun multivariat menunjukkan hasil yang konsisten. Namun, terdapat satu variabel, yakni riwayat komplikasi yang merupakan determinan penting dari hasil analisis multivariat walaupun tidak mempunyai hubungan signifikan pada analisis bivariat. Model terakhir analisis multivariat regresi logistik menunjukkan bahwa tempat tinggal merupakan variabel yang paling memengaruhi pemanfaatan kedua bentuk pelayanan kesehatan ibu. Determinan penting lainnya dalam pemanfaatan pelayanan persalinan adalah riwayat komplikasi, pendapatan keluarga, umur, dan pendidikan ibu.

\section{Saran}

Penelitian ini menggunakan data sekunder hasil Riskesdas 2010 sehingga mempunyai keterbatasan untuk mengungkapkan faktor determinan pemanfaatan pelayanan penting lainnya, di antaranya belum mengaitkan variabel aksesibilitas fisik berupa jarak rumah dengan jalan dan fasilitas terdekat. Untuk itu perlu dilakukan penelitian lebih lanjut dengan menggunakan jarak yang sebenarnya. Penelitian selanjutnya juga sebaiknya mengaitkan antara kualitas pelayanan dengan pola pemanfaatan pelayanan kesehatan yang berimplikasi pada kepuasan perempuan terhadap pelayanan kesehatan yang diberikan karena dapat menyebabkan rendahnya penggunaan pelayanan kesehatan. Penelitian ke depan juga harus mengeksplorasi faktor-faktor kontekstual seperti aktivitas ekonomi atau kepadatan penduduk dengan pertimbangan perkembangan ekonomi masyarakat atau penyebaran penduduk memberikan pengaruh pada pemanfaatan pelayanan kesehatan ibu.

\section{Daftar Pustaka}

1. Kementerian Kesehatan Republik Indonesia. Pedoman pelaksanaan pelayanan kesehatan ibu di fasilitas kesehatan. Jakarta: Kementerian Kesehatan Republik Indonesia; 2010.

2. Republika. Inilah sembilan provinsi penyumbang kematian ibu terbesar; 2012 [serial on the internet] 2012 [diakses tanggal 2011 Oct 11]. Diunduh dari: www.republika.co.id./berita/nasional/12/04/30.

3. Dinas Kesehatan Provinsi Jawa Barat. Laporan Tahunan Propinsi Jawa Barat. Bandung: Dinas Kesehatan Jawa Barat; 2010.

4. Departemen Kesehatan Republik Indonesia. Kebijakan dan strategi nasional kesehatan reproduksi di Indonesia. Jakarta: Kementerian Kesehatan Republik Indonesia; 2005.

5. Kementerian Kesehatan Republik Indonesia. Profil kesehatan Indonesia. Jakarta: Kementerian Kesehatan Republik Indonesia; 2010.

6. Kausar F, Griffiths P, Matthews Z. Opportunities and choices working papers No. 20: poverty and maternal health care utilisation in Maharashtra: associated influences on infant mortality and morbidity, Departement of Social Statistics, University Of Southhampton, UK. New York: Population Association of America; 1999 [cited 2012 Sept 15]. Available from: http://www.94.126.106.9/R4D/PDF/Outputs/HOppsWork20.pdf

7. McDonagh M. Review article: is antenatal care effective in reducing maternal morbidity and mortality? Health Policy and Planning. 1996; 11 (1): 1-15.

8. Thaddeus S, Maine D. Too far to walk: maternal mortality in context. Social Science of Medicine. 1994; 38: 1091-110.

9. Griffiths P, Stephenson R. Understanding users' perspectives of barriers to maternal health care use in Maharashtra, India. Journal of Biosocial Science. 2001; 33 (3): 339-59.

10. Gabrysch S, Campbell OM. Still too far to walk: Literature review of the determinants of delivery service use. BMC Pregnancy Childbirth. 2009; 9: 34.

11. Elo IT. Utilization of maternal health-care services in Peru: the role of women's education. Health Trans Rev [serial on the internet]. 1992; 2(1): 49-69 [cited 2012 Oct 20]. Available from: http://www.htc.anu.edu.au/pdfs/Elo1.pdf

12. Raghupathy $\mathrm{S}$. Education and the use of maternal health care in Thailand. Social Science and Medicine. 1996; 43 (4): 459-71.

13. Singh PK, Rai RK, Alagarajan M, Singh L. Determinants of maternity care services utilization among married adolescents in Rural India. Plos One [serial on the internet] 7(2):e31666 [cited 2012 Feb 
15]. Available from: http://www.plosone.org.

14. Magadi MA, Agwanda AO, Obare FO. A comparative analysis of the use of maternal health services between teenagers and older mothers in sub-Saharan Africa: evidence from Demographic and Health Surveys (DHS). Social Science and Medicine. 2007; 64 (6): 131125.

15. Ochako R, Fotso JC, Ikamari L, Khasakhala A. Utilization of maternal health services among young women in Kenya: insights from
Kenya Demographic and Health Survey, 2003. BMC Pregnancy and Childbirth. 2011; 11: 1 .

16. Badan Pusat Statistik. Peraturan Kepala Badan Pusat Statistik No. 37 Tahun 2010. $2^{\text {nd }}$ ed. Jakarta: Badan Pusat Statistik; 2010 [diakses tanggal 1 November 2012]. Diunduh dari: http://www.bps.go.id.

17. Navaneetham A, Dharmalingam. Utilization of maternal health care services in South India. Social Science and Medicine. 2002; 55 (10): 1849-69. 